\title{
THE RELATIONSHIP BETWEEN CULTURE AND STRATEGY - A MANAGERIAL PERSPECTIVE APPROACH
}

\author{
Associate Professor Florin Lucian Isac, PhD \\ „Aurel Vlaicu” University of Arad, Faculty of Economics \\ florinisac72@yahoo.com
}

Associate Professor Eugen Florin Remes, PhD

„Vasile Goldis” Western University of Arad, Faculty of Economics

eugenremes@yahoo.com

(Received: June 2018; Accepted: August 2018)

\begin{abstract}
:
Culture is a concept with different meanings, which is in close contact with the business world as well. Its influence on managerial activities within current organizations cannot be questioned, especially in the existing political, economic and social context.

Nowadays, one of the specific ways of formulating and implementing strategies at the level of companies is related to the change of organizational culture.

This paper aims to highlight, from a managerial perspective, the way in which the existing strategies at the organizational level are influenced by different cultural contexts.

Sometimes strategy can be considered as a variable determined and constrained by the culture in which it is defined. It is not limited to the reflection and expression of culture but rather influences and changes it.
\end{abstract}

Keyword: culture, strategy, management, organisations

JEL Classification: M14, L10

\section{Introduction}

Since the beginning of international trade, culture has played an important role for individuals or entities seeking to initiate a transaction. Culture acts as an important force, modeling the perceptions, dispositions and behaviors of individuals (Triandis, 1989), influencing the willingness of individuals to start a business and, consequently, their probability of failure or success. According to Geert Hofstede (1980, 2001), culture is "the collective mind programming", "a shared mental software." Culture is both a source and a manifestation of group distinction and diversity.

From a historical point of view, nations are political expressions of cultural similarities. National governments shape the work culture through specific legislation and provide a basis for how to operate multinational firms, both within the country and abroad.

76 S sciendo Studia Universitatis "Vasile Goldis" Arad. Economics Series Vol 28 Issue 3/2018 ISSN: 1584-2339; (online) ISSN: 2285 - 3065

Web: publicatii.uvvg.ro/index.php/studiaeconomia.Pages $76-85$ 
Isac, F.L., Remes, E.F. (2018)

The relationship between culture and strategy - a managerial perspective approach

The concept of strategy has preoccupied the attention of specialists in various fields. Among them, the interest for our work is the organizational field and, above all, the managerial one. For Igor Ansoff (1968) strategy is "a decision that runs relations between the enterprise and the environment", and Henry Mintzberg (Vagu, Stegăroiu et al., 2014) offers for the enterprise strategy the following five meanings: plan, ploy, pattern, position and perspective.

Schneider, Barsoux and Stahl (2014) refer to the relationship between culture and strategy, appreciating that their definition of culture - a solution to problems of external adaptation and internal integration - can be used equally well in defining the concept of strategy.

A strong culture must be adaptive and strategically appropriate to support the company's orientation towards development and performance (Huţu, 1999). Companies build value systems that express the essence of their philosophy of success, and provide a common direction to sustain performance. Establishing the value system in close correlation with efficiency and effectiveness has special implications for how to set mission, goals and strategies, structure formation, and plan implementation.

\section{National culture and managerial strategy}

National culture is a variable often used in the strategic approach, although its treatment as a concept, construct and measure tends to be limited as a goal and especially as a depth. Unlike in the field of international affairs, where culture is a major construct, in the sphere of strategy, culture is much more variable, with a rather controlling role (Ronen and Shenkar, 2017).

Culture can be seen as a strategy for solving the problems that have arisen over time, and the two concepts can be interconnected. Schneider (1989) developed a model of the interaction between societal culture and strategy formulation. By formulating the strategy, the author understands the organization's alignment with the environment, and its main argument is that societal culture influences both the nature of the relationship between the organization and the environment and the nature of the relationships between the members of the organization. Schneider identifies two different models of strategy formulation. The first is more appropriate for companies that belong to cultures with a high level of individualism, a strong avoidance of uncertainty and a great power distance, and the second with low scores on the same cultural dimensions.

National culture influences both how to choose a strategy and how to implement it, involving leadership and decision-making processes. Thus, Swedish managers spend more time making decisions than their English colleagues, who, on the other hand, require more interaction and consultation with experts (Tayeb, 2003). The 
Isac, F.L., Remes, E.F. (2018)

The relationship between culture and strategy - a managerial perspective approach

same author mentions another area where national culture has an influence on strategy: the products and services sector. Consumer demand for different products and services varies from one country to another, from one region to another. The company needs to consider consumer preferences when analyzing resources and capabilities, especially when it wants to expand its business in the international environment.

Table 1

Two models of strategy formulation

\begin{tabular}{|c|c|c|}
\hline Activity & Model 1 & Model 2 \\
\hline Scanning behavior & $\begin{array}{l}\text { Search: active, focussed, } \\
\text { systematic }\end{array}$ & $\begin{array}{l}\text { Monitor: passive, } \\
\text { broad, nonsystematic }\end{array}$ \\
\hline $\begin{array}{l}\text { Selection (type of } \\
\text { information, sources) }\end{array}$ & $\begin{array}{l}\text { Quantitative objective, } \\
\text { expert }\end{array}$ & $\begin{array}{l}\text { Qualitative subjective, } \\
\text { personal }\end{array}$ \\
\hline Interpretation & Analytic & Intuitive \\
\hline Validation & $\begin{array}{l}\text { personal edict bureaucratic } \\
\text { rules, historical precedent }\end{array}$ & Consensus, political \\
\hline Priorities & $\begin{array}{l}\text { Urgency, certainty, task } \\
\text { orientation }\end{array}$ & $\begin{array}{l}\text { Less urgency or certainty, } \\
\text { people orientation }\end{array}$ \\
\hline Overall & Top-down, elite dominated & Bottom-up, consensus based \\
\hline $\begin{array}{l}\text { Cultural Variables } \\
\text { - control } \\
\text { - uncertainty } \\
\text { - activity } \\
\text { - hierarchy } \\
\text { - peer } \\
\text { - relationships }\end{array}$ & $\begin{array}{l}\text { High } \\
\text { Reduction } \\
\text { Proactive } \\
\text { High } \\
\text { Individual } \\
\text { Task oriented }\end{array}$ & $\begin{array}{l}\text { Low } \\
\text { Tolerance } \\
\text { Reactive } \\
\text { Low } \\
\text { Group } \\
\text { People oriented }\end{array}$ \\
\hline
\end{tabular}

Source: slightly adapted from Schneider S.C., (1989), Strategy Formulation. The Impact of National Culture, Organization Studies, pp. 149-162

The perception of cultural distance influences strategic choice. Business partners from another country will develop more trust in their home country if there are many similarities between the two business cultures, such as between US and British culture.

Cultural dimension short-term orientation vs. long-term orientation seems to influence the strategic choices at different levels of analysis. According to Geert Hofstede's approach, "long-term orientation stands for the fostering of virtues oriented toward future rewards - in particular, perseverance and thrift. Its opposite pole, short-term orientation, stands for the fostering of virtues related to the past and present - in particular, respect for tradition, preservation of "face" and fulfilling social obligations" (Hofstede, Hofstede and Minkov, 2012). China, Southeast Asian countries called dragons or tigers, alongside Japan occupy the

78 S sciendo Studia Universitatis "Vasile Goldis" Arad. Economics Series Vol 28 Issue 3/2018 ISSN: 1584-2339; (online) ISSN: $2285-3065$

Web: publicatii.uvvg.ro/index.php/studiaeconomia.Pages $76-85$ 
Isac, F.L., Remes, E.F. (2018)

The relationship between culture and strategy - a managerial perspective approach

leading positions in the dimension of "long-term orientation". Americans can focus on their strategic short-term profit choices, while the Japanese prefer to build the future through investment, research and development, giving priority to increasing market share (Deresky, 2014). Risk orientation has been identified as an explanation for choosing between different ways of entering a company in a foreign market ("equity mode" vs. "non-equity mode") (Pan and Tse, 2000). "Equity modes" (joint ventures, green fields) imply a high level of control from the headquarters of the company, giving it a considerable investment attachment. "Non-equity modes" imply a lower level of control because the volume and scope of investment are lower. Risk orientation is closely linked to Hofstede's "avoidance of uncertainty" dimension. Companies from countries with high uncertainty avoidance (those in Africa or Latin America) tend to prefer "non-equity modes" to reduce their exposure to risk, while organizations from countries with low uncertainty avoidance will be more inclined to adopt "equity mode". Pan and Tse (2000) also found that companies in countries with high power distance tend to adopt "equity entry mode" when they want to expand abroad.

The key role in implementing the strategy when the company expands to another country is the country manager. It is in the midst of a strategic tension created between the need to defend the company's market position against global competitors and the need to meet the demands of the local subsidiary (Browaeys and Price, 2011). Thus, this manager has the role of a "cultural interpreter" and must have important intercultural communication skills, understand the cultural norms of the host country, but at the same time he must communicate to local employees the corporate goals, strategies and values.

\section{Differentiation between the West and the East in thinking and developing strategies}

The increased interest in strategies in the last two decades of the 20th century is due to research conducted in the USA. The large number of corporations operating in the US economy has led to increased focus on company strategies. North American companies seem to have ambitious, explicit and quantifiable goals, and their managers assume responsibility for formulating, communicating and implementing strategies. US executives are familiar with key success factors (KSFs) in the industry they operate in, and can easily tell examples of strategic decisions in their business: entering new markets, reconfiguring the company's value chain, relocating (Lawrence and Edwards, 2000). The famous western authors, Mintzberg, Ahlstrand and Lampel (1998), group strategic approaches in ten schools (design, planning, positioning, entrepreneurship, cognitive, learning, power, cultural, environmental, configuration). The design school, considered to be 
Isac, F.L., Remes, E.F. (2018)

The relationship between culture and strategy - a managerial perspective approach

the most influential approach to the strategic process, focuses on creating and implementing the strategy as a result of internal and external environment analysis. The working hypotheses of this school are (Brătianu, 2015):

- Designing the strategy is a result of rational thinking;

- Responsibility for developing the strategy lies with the general manager;

- The strategy is a solution to a specific problem and does not contain generic elements.

The planning school was based on Igor Ansoff's vision and promoted algorithmic structuring and large-scale use of quantitative methods. The relative stability of the US economy in the 1960-1970 periods marked a strong development of strategic planning, followed by a decline. This was based on the modular American (mechanical) thinking, in which the general manager evaluated and approved the strategic plan, and the experts elaborated it (Brătianu, 2015).

In their work "Pragmatic Strategy. Eastern Wisdom, Global Success", Nonaka and Zhu (2012) oppose the western perspective based on rationality and the time separation of the concept of its implementation strategy, an integrative perspective based on Confucian philosophy and pragmatism of Japanese management. Important features of Confucianism are pragmatism (with a different sense of opportunism) and holistic thinking, based on interconnection, emotional and spiritual thinking. In this perspective, strategies are formed on their way to the future, building it progressively. Strategy is the art of realizing the things proposed by interpreting the context, making decisions in complexity, using collective judgments, situations of ambiguity and uncertainty (Brătianu, 2015).

Chinese companies experience difficulties in strategic analysis due to the existence of many interconnected factors and a constant change in their external environment. Strategic decisions are typically adopted by senior management, small business owners, or chairman of the board of directors' at large companies.

One of the most important strategic concerns is diversification, seen as a means of mitigating risks in a dynamic and flexible market. Implementation of strategy has priority in the strategic management of Chinese companies. They focus on the speed of the process (essential in a turbulent environment) and managerial experience plays an essential role (Huang, 2009).

In Japan, the priority given to growth leads managers to make judgments from the perspective of continued growth. If the demand is high, Japanese firms are adopting a "doubling" strategy, through which they manage to double their production capacity over a 2-4 year period.

Companies show a lasting interest in the activity of competitors, trying to overcome them or, if they fail, to be different from them and identify market niches. The creation and exploitation of competitive advantage remains a central

80 sciendo Studia Universitatis "Vasile Goldis" Arad. Economics Series Vol 28 Issue 3/2018 ISSN: 1584-2339; (online) ISSN: $2285-3065$

Web: publicatii.uvvg.ro/index.php/studiaeconomia.Pages $76-85$ 
Isac, F.L., Remes, E.F. (2018)

The relationship between culture and strategy - a managerial perspective approach

concern of Japanese companies, technologies developed as a result of research \& development investments representing the basis of this advantage in the last period (Burduş, 2012).

A comparative synthesis of the characteristics of competitive strategies in the US and Japan is presented in Table 2.

Comparison between the characteristics

Table 2

f competitive strategies in Japan and the US

\begin{tabular}{|l|l|l|}
\hline \multicolumn{1}{|c|}{ Feature } & \multicolumn{1}{|c|}{ Japan } & \multicolumn{1}{c|}{ Traditional US } \\
\hline Goal & Long-term growth & Short-term profits \\
\hline Investment & $\begin{array}{l}\text { Emphasis on R\&D and } \\
\text { employee training }\end{array}$ & Less capital investment \\
\hline $\begin{array}{l}\text { Cooperation between } \\
\text { suppliers, makers and sales } \\
\text { channels }\end{array}$ & $\begin{array}{l}\text { Good cooperation between } \\
\text { suppliers, manufacturers and } \\
\text { vendors (simultaneous } \\
\text { engineering, JIT systems) }\end{array}$ & $\begin{array}{l}\text { Open bidding, independent } \\
\text { sales channels (long } \\
\text { development time, large } \\
\text { inventory) }\end{array}$ \\
\hline $\begin{array}{l}\text { Interface between } \\
\text { departments }\end{array}$ & $\begin{array}{l}\text { Good interface } \\
\text { (simultaneous engeneering) }\end{array}$ & $\begin{array}{l}\text { Poor interface between } \\
\text { development, production } \\
\text { and sales department }\end{array}$ \\
\hline $\begin{array}{l}\text { Focus on means of } \\
\text { competition }\end{array}$ & Quality & $\begin{array}{l}\text { Cost (there is an economic } \\
\text { quality level) }\end{array}$ \\
\hline Customer relations & Customer oriented & Mass production, mass sales \\
\hline Attitudes & Me-too, strong competition & Niche seeking \\
\hline
\end{tabular}

Source: Kono T., Clegg S., (2001), Trends in Japanese Management. Continuing Strengths, Current Problems and Changing Priorities, Palgrave, p.194

\section{Organizational culture and company strategy}

Schein (2010) defines the culture of a group as "a pattern of shared basic assumptions learned by a group as it solved its problems of external adaptation and internal integration, which worked well enough to be considered valid and therefore to be taught to new members as the correct way to perceive, think, and feel in relation to those problems". Organizational culture implies the existence of values and patterns of beliefs and behavior shared by members of a particular organization. Ideally, the strategic decisions adopted by the organization's top management should be in line with the culture of the organization. Strategies that run counter to cultural norms are hard to implement (Parnell, 2014).

Organizational culture can be a basis for building a sustainable competitive advantage. In order for this to happen effectively, the organizational culture (viewed according to the resource-based approach) must be valuable, rare, difficult to imitate, and the firm must be organized to have the ability to absorb the value created (Rothaermel, F., 2015). Jay Barney has identified the conditions under 
Isac, F.L., Remes, E.F. (2018)

The relationship between culture and strategy - a managerial perspective approach

which a particular culture can be the source of a sustainable competitive advantage. Thus, it is important to have a link between the values and other elements of the organization's culture and the value that the company creates for the client. A creative value culture can be analyzed as any other resource or capability of the firm. When a company that comes from a national culture that supports performance adopts a diversification strategy on international markets, it will compete with foreign firms whose crops may not be so supportive. It is the known case of the Japanese automobile manufacturers that have penetrated the US market, the success of such firms as Honda being often attributed to the cultural attributes of Japanese firms (Besanko et al., 2013).

If a company culture is a source of competitive advantage, a large number of competitors will try to imitate such a culture. However, there are two reasons why it is difficult to imitate successful business cultures: causal ambiguity and social complexity. For companies with dominant cultural uniqueness it is difficult to establish a causal relationship between values, norms, artifacts and performance. Organizational culture encompasses an ensemble of complex social relationships that include not only interactions between members of different hierarchical levels, but also contacts established with actors of the external environment.

A key feature of organizational culture is the founder of the company, which can hold solid beliefs about business practices (Parnell, 2014). Concepts of success of the founders and top leaders of the company form the foundation of the company culture (remarkable are the strong influences on McDonald's and Apple's founders, Ray Kroc and Steve Jobs, respectively). Sam Walton, Walmart's founder, also embodies the retailer's cost leadership strategy. The culture originally imprinted by founders is strengthened by their strong preference to recruit, retain and promote employees who adhere to the same set of values (Schneider, Goldstein and Smith, 1995). As employee values and norms become more and more similar, organizational culture is more powerful and full of elements of distinctiveness. A side effect of this situation is "groupthink", when individuals coalesce around a leader without evaluating or criticizing his views and assumptions. Cohesive and low-diversification groups will probably be inclined towards this pattern of thinking, which may lead to deformed decision-making processes (Rothaermel, 2015).

It is important to develop a strong and strategically relevant culture in the early years of existence of the firm. Research shows that control mechanisms, culture, and initial structure (established in a new firm) are important predictors of subsequent success (Baron, Hannan and Burton, 2001). Also, the founding executives impose a mobilizing effect on employees on the implementation of the

82 Sciendo Studia Universitatis "Vasile Goldis" Arad. Economics Series Vol 28 Issue 3/2018 ISSN: 1584-2339; (online) ISSN: $2285-3065$

Web: publicatii.uvvg.ro/index.php/studiaeconomia.Pages $76-85$ 
Isac, F.L., Remes, E.F. (2018)

The relationship between culture and strategy - a managerial perspective approach

strategy, higher than the directors who are not founders, thus achieving a higher performance.

There are some studies that have analyzed the links between culture and strategy. Baird, Harrison and Reeve (2007) have left the assumption that organizational culture and strategy are mutually conditioned, the authors' interest being to operationalize this relationship, to demonstrate that in order to implement a specific strategy it is necessary to build a certain organizational culture or that a specific organizational culture leads to the choice and implementation of a specific strategy. This reciprocal conditioning also applies to business functional strategies, such as those in the human resources field. Chow and Liu (2009) have established the hypothesis that the effectiveness of human resources strategy depends on its compatibility with organizational culture, but also with the overall business strategy of the enterprise. In their research, culture does not directly influence the choice of human resources strategy, but only the effects of this strategy on company performance and fluctuation rate of staff. Naranjo-Valencia et. al. (2011) have appreciated that organizational culture determines the strategy, thereby confirming in their study that the type of strategy used depends on the culture of the respective organization. At the same time, they discovered that innovation strategies are produced by organizational cultures of the adhocratic type, while hierarchical cultures offer an open field of imitation. Ahmadi et. al. (2012) studied the relationship between the typologies of organizational culture proposed by Cameron and Quinn (1999) and the strategy implementation in a bank in Iran. They found a significant relationship between organizational culture and strategy implementation. All types of organizational culture analyzed had significant relationships with the implementation process, but the degree of influence was different from clan culture (most effective) to hierarchy culture (the least effective).

\section{Conclusions}

National culture has an impact on the strategy, both in the conception phase and in the implementation phase. The well-known Dutch researcher Geert Hofstede underlined the importance of incorporating cultural dimensions in the process of designing and implementing the strategy. The process of globalization, more and more pronounced and full of new valences, involves ever more intense contact between different national or even regional cultures. Global strategic choices will become increasingly complex, so businesses will have to incorporate cultural elements into their global decisions. Studies that seek to identify links between the dimensions of national cultures and elements of the process of designing or implementing strategies are still few. In addition, strategy-oriented studies rarely use cultural clusters to predict strategic behavior. 
Isac, F.L., Remes, E.F. (2018)

The relationship between culture and strategy - a managerial perspective approach

An important challenge for managers occurs when strategic alliances are established between partners from different institutional environments, such as countries with a stable market economy and countries in transition. They will be faced with challenges related to the reconciliation of values, norms and practices in the respective cultures. Similar issues may arise when a multinational European company, for example, due to rising revenues on the North American market, decides to move its headquarters for some product lines in the US. The European managers of these headquarters found that due to the American tendency to be individualized and informal, they did not respond adequately to directives from European managers.

At the same time, organizational culture influences the strategy, both in the formulation process and its implementation. It determines how top management interprets the external environment and the company's internal resources. In the implementation stage of the strategy, organizational culture confers (or not) the legitimacy of the chosen strategy. Thus, the important role of the manager is to identify ways of harmonizing organizational culture and strategy. In this context, it is important to deepen the links between organizational culture (and its different dimensions), strategy and performance.

\section{References}

1. Ahmadi S.A.A., Salamzadeh Y., Daraei M., Akbari J., (2012), Relationship between Organizational Culture and Strategy Implementation: Typologies and Dimensions, Global Business and Management Research: An International Journal, vol. 4., no. 3\&4, pp. 286-299

2. Ansoff I., (1968), Stratégie du développement de l'entreprise, Hommes et Techniques, Paris, 1968

3. Baird K., Harrison G., Reeve R., (2007), The Culture of Australian Organizations and Its Relation With Strategy, International Journal of Business Studies, 15.1, pp. 15-41

4. Baron J.N., Hannan M.T., Burton M.D., (2001), Labor Pains: Change in Organizational Models and Employee Turnover in Young High-tech Firms, American Journal of Sociology, 106, pp. 960-1012

5. Besanko D. et.al., (2013), Economics of Strategy, 6th edition, Wiley

6. Brătianu C., (2015), Gândirea strategică, Ed. Prouniversitaria, Bucureşti

7. Browaeys M.J., Price R., (2011), Understanding Cross-Cultural Management, second edition, Financial Times Prentice Hall

8. Burduş E., (2012) Management comparat internaţional, ediţia a patra, Ed. Prouniversitaria, Bucureşti

9. Chow I.H.S., Liu S.S., (2009), The effect of aligning organizational culture and business strategy with HR systems on firm performance in Chinese entreprises, The International Journal of Human Resource Management, no. 11., vol. 20, pp. 2292-2310 
Isac, F.L., Remes, E.F. (2018)

The relationship between culture and strategy - a managerial perspective approach

10. Deresky H., (2014), International Management, Managing Across Borders and Cultures, Pearson

11. Hofstede G., Hofstede G.J., Minkov M., (2012), Culturi şi organizaţii. Softul mental, Ed. Humanitas, Bucureşti

12. Huang X.C., (2009), The Influence of National Culture, History and Institution on Strategic Management in Chinese Firms: A Complexity Based Perspective, International Journal of Business Studies, 17(1); pp. 1-18

13. Huţu C.A., (1999), Cultură organizaţională şi transfer de tehnologie, Ed. Economică, Bucureşti

14. Kono T., Clegg S., (2001), Trends in Japanese Management. Continuing Strengths, Current Problems and Changing Priorities, Palgrave

15. Lawrence P., Edwards V., (2000), Management in Western Europe, Palgrave Mac Millan

16. Mintzberg H., Ahlstrand B., Lampel J., (1998), Strategy safari. The complete guide to the wilds of strategic management, FT Prentice Hall, London

17. Naranjo-Valencia J.C, Jiménez-Jiménez D., Sanz-Valle R., (2011), Innovation or imitation? The role of organizational culture, Management Decision, Vol. 49, No. 1, pp. $55-72$

18. Nonaka I., Zhu Z., (2012), Pragmatic strategy. Eastern wisdom, global success, Cambridge University Press

19. Pan Y., Tse D.K., (2000), The Hierarchical Model of Market Entry Modes, Journal of International Business Studies, 31(4), pp. 535-554

20. Parnell J.A., (2014), Strategic Management. Theory and Practice, SAGE Publications, Inc.

21. Ronen S., Shenkar O., (2017), Navigating Global Business. A Cultural Compass, Cambridge University Press

22. Rothaermel F.T., (2015), Strategic Management, 2nd edition, McGraw-Hill

23. Schein E.H., (2010), Organizational Culture and Leadership, fourth edition, Jossey Bass, Wiley

24. Schneider B., Goldstein H.W., Smith D.B., (1995), The ASA framework: An update, Personnel Psychology 48, pp. 747-773

25. Schneider S.C., (1989), Strategy Formulation. The Impact of National Culture, Organization Studies, pp. 149-162

26. Schneider S.C., Barsoux J.L., Stahl G.K., (2014), Managing across cultures, third edition, Pearson

27. Tayeb M., (2003), International Management. Theories and Practices, FT Prentice Hall

28. Triandis H.C., (1989), The self and social behavior in differing cultural contexts, Psychological Review, 96, pp. 506-520

29. Vagu P., Stegăroiu I., Croitoru G., Duică A., Duică M., (2014), Strategii manageriale, Ed. Prouniversitaria, Bucureşti 